\title{
Simultaneous determination of mycotoxins in peruvian purple maize
}

\author{
Natalia Hoffmann Rossi ${ }^{1}$ (D) Maurício Schneider Oliveira ${ }^{2}$ iD Liziane Rachel da Silva Wovst $^{2}$ iD \\ Carlos Augusto Mallmann ${ }^{1 *}$ iD
}

${ }^{1}$ Laboratório de Análises Micotoxicológicas (LAMIC), Universidade Federal de Santa Maria (UFSM), 97119-900, Santa Maria, RS, Brasil. E-mail: mallmann@lamic.com.br. "Corresponding author.

${ }^{2}$ Soluções analíticas microbiológicas e tecnológicas (SAMITEC), Santa Maria, RS, Brasil.

ABSTRACT: Purple maize is an important foodstuff for the Peruvian people. Its unique nutritional and antioxidant characteristics makes it widely exported to other countries. However, when contaminated by fungi, it can trigger numerous health problems in the consumers. This study aimed to evaluate the presence of 27 mycotoxins in 63 samples of purple maize collected in Peru. Frequency of occurrence and mean concentration of the following mycotoxins were determined: alternariolmetileter (AME), alternariol (AOH), tentoxin, neosolaniol, nivalenol, wortmannin, deoxynivalenol, 3-acetyl deoxynivalenol, 15 -acetyl deoxynivalenol, zearalenone, aflatoxin $B_{l}$, aflatoxin $B_{2}$, aflatoxin $G_{l}$, aflatoxin $G$, fumonisin $B_{l}$, fumonisin $B_{2}$, fumonisin $B_{3}$, ochratoxin A, ochratoxin $\alpha, T-2$ toxin, HT-2 toxin, fusarenon $x$, cyclopiazonic acid, gliotoxin, agroclavin and citreoviridin. The main mycotoxins reported in purple maize were $A M E$ and $A O H$, with a frequency of occurrence of 14.3 and $7.9 \%$, and mean concentration of $23.3 \%$ and $1.8 \%$, respectively. AME and $A O H$ do not have guidance levels in the Brazilian legislation. Contrastingly, levels of mycotoxins which are within the standards of the country's regulations were below the limit of quantification. The present results suggested that purple maize is a raw material with a great potential for the production and industrialization of special products. Key words: Zea mays L, alternariolmetileter, alternariol, secondary metabolites.

Determinação simultânea de micotoxinas em milho roxo peruano

RESUMO: O milho roxo é um alimento importante para o povo peruano. Suas características nutricionais e antioxidantes únicas fazem com que seja amplamente exportado para outros países. No entanto, quando contaminado por fungos, pode desencadear inúmeros problemas de saúde nos consumidores. Este estudo teve como objetivo avaliar a presença de 27 micotoxinas em 63 amostras de milho roxo coletadas no Peru. A frequência de ocorrência e a concentração média das seguintes micotoxinas foram determinadas: alternariolmetileter (AME), alternariol (AOH), tentoxina, neosolaniol, nivalenol, wortmanina, desoxinivalenol, 3-acetil desoxinivalenol, 15-acetil desoxinivalenol, zearalenona, aflatoxina B1, aflatoxina B2, aflatoxina $G 1$, aflatoxina $G 2$, fumonisina B1, fumonisina B2, fumonisina B3, ocratoxina A, ocratoxina, toxina T-2, toxina HT-2, fusarenona $x$, ácido ciclopiazonico, gliotoxina, agroclavina e citreoviridina. As principais micotoxinas encontradas no milho roxo foram $A M E$ e $A O H$, com frequência de ocorrência de 14,3\% e 7,9\% e concentração média de 23,3\% e 1,8\%, respectivamente. AME e AOH não possuem níveis de orientação na legislação brasileira. Contrastantemente, os níveis de micotoxinas que estão dentro dos padrões das regulamentações do país estavam abaixo do limite de quantificação. Os presentes resultados sugerem que o milho roxo é uma matériaprima com grande potencial para a produção e industrialização de produtos especiais.

Palavras-chave: Zea mays L, alternariolmetileter, alternariol, metabólitos secundários.

The purple race of Zea mays L. is a native plant from America. It was one of the main foodstuffs of indigenous peoples in the pre-Columbian era, and several medicinal properties have been attributed to it; hence its industrial and export potential. Chemical components of the purple maize are essences, salicylic acid, fats, resins, saponins, potassium and sodium salts, sulfur and phosphorus, and especially phenolic compounds (ARROYO et al., 2007).
Mycotoxins are toxic secondary metabolites which result from the contamination of the food, and are produced by a variety of fungi species. They may cause economic losses and affect human and animal health when contaminated food is ingested by them (HUSSEIN \& BRASSEL, 2001). The Food and Agriculture Organization of the United Nations (FAO) has estimated that every year $25 \%$ of the food crops worldwide are contaminated by mycotoxins (BOUTRIF \& CANET, 1998). 
The high incidence of mycotoxin contamination of maize demands more studies to be done so that only products having low concentrations of mycotoxins are used in the industry. Then, this study aimed to investigate the concentrations of 27 mycotoxins in Peruvian purple maize through liquid chromatography coupled to mass spectrometry.

Sixty-three samples of purple maize were obtained from commercial establishments in Peru from March to April 2017. Each sample was ground through a $1.5 \mathrm{~mm}$ sieve (ZM 200; Retsch, Haan, Germany), homogenized and then weighed in a 50$\mathrm{mL}$ polypropylene tube.

Briefly, the analyses were carried out with a LC-MS/MS QTrap 5500 System (ABSCIEX, Foster City, CA, EUA) equipped with an electrospray ionization source (ESI) in positive and negative mode (Turbo Ion Spray), and a 1290 Infinity HPLC System (Agilent, Waldbronn, Alemanha). Chromatographic separation was done at $30^{\circ} \mathrm{C}$ with an Agilent Zorbax Eclipse C18 column $(4.6$ x $150 \mathrm{~mm}, 5 \mu \mathrm{m}$ particle diameter). Methanol, water and ammonium acetate were used to compose the mobile phase, in a flux of $0.8 \mathrm{~mL} \mathrm{~min}^{-1}$, with an injection volume of $40 \mu \mathrm{L}$.

This is the first scientific report on the quantification of mycotoxins in purple maize. Of the 27 mycotoxins analyzed in the 63 samples of Peruvian purple maize, only two were detected: alternariolmetileter (AME) and alternariol (AOH). None of these metabolites is within the standards of the Brazilian legislation. Coincident occurrence of $\mathrm{AME}$ and $\mathrm{AOH}$ was reported in $7.9 \%$ of the samples (data not shown). Co-occurrence of mycotoxins has been recurrently reported in maize samples, though not of AME and AOH (MORENO et al., 2009; SERRANO et al., 2012; KROUT-GREENBERG et al., 2013; JAMES et al., 2018). Furthermore, 54 samples did not present mycotoxins at detectable levels (within the LQ), and none of the analyzed metabolites with guidance levels in Brazilian law were detected (BRASIL, 2011).

AME was detected in $12.7 \%$ of samples, with a mean concentration of $23.3 \mu \mathrm{g} \mathrm{kg}^{-1}$. It was the most frequent mycotoxin reported in the analyzed samples (Table 1). It is present in a diversity of foodstuffs (PATRIARCA, 2016). According to TIEMANN et al. (2009), ingestion of food contaminated with Alternaria toxin may affect the reproductive development of swine and other mammal species. Moreover, chronic exposure through the diet has shown to exceed the limit of toxicological warning for this mycotoxin (EFSA, 2011). Therefore, the present results indicated the need for additional toxicity data for AME in humans.

The greatest concentration reported for AME was $86.8 \mu \mathrm{g} \mathrm{kg}^{-1}$ (Table 1). It must be highlighted that, along with $\mathrm{AOH}$ and all of the mycotoxins belonging to the genus Alternaria, AME does not have guidance levels (HAJNAL et al., 2016). The latter authors stated that AME can be extracted from whole wheat flour by means of specific processes, thus resulting in a $94.5 \%$ extraction of the metabolite.

The highest concentration of $\mathrm{AOH}$ reported in the purple maize samples was $3.75 \mu \mathrm{g}$ $\mathrm{kg}^{-1}$ (Table 1). Since there are no standards for this mycotoxin within the legislation, it is not known whether this is a high or low amount. Nonetheless, it has been shown that $\mathrm{AOH}$ is harmful to poultry health; synergistic estrogenic effects have been observed when binary combinations of $\mathrm{AOH}$ and zearalenone or $\alpha$-zearalenol were tested (LEE et al., 2015; VEJDOVSZKY et al., 2017).

Present in $7.9 \%$ of the analyzed samples, $\mathrm{AOH}$ was less frequent than AME; both mycotoxins are produced by Alternaria fungi (LEE et al., 2015). These mycotoxins do not have guidance levels in any national or international legislations (HAJNAL et al., 2016), and this is likely to contribute to the fact that only a few scientific studies investigate their presence in maize, and none in purple maize.

None of the mycotoxins most frequently detected in yellow maize reached the LQ in the current study (Table 1). Deoxinivalenol, zearalenone, aflatoxinas $\mathrm{B}_{1}$ and $\mathrm{B}_{2}$ and fumonisins are the mycotoxins most often reported and also the ones to cause the greatest concerns in yellow maize (KROUT-GREENBERG et al., 2013; ADEYEYE, 2019). Serious outcomes may be produced in humans and animals as a result of their ingestion (BELHASSEN et al., 2015).

With regard to the presence of toxins produced by fungi, the present findings allowed to characterize the purple maize as an excellent raw material to be used in the food and feed industry. Moreover, the unprecedented data conveyed herein contributes to the development of strategies employing this special ingredient with extremely low levels of these noxious substances, which are so deleterious to human and animal health. Subsequent research on mycotoxins should be carried out in order to complement the data obtained in this investing, and thus feed the Peruvian authorities with scientific information to allow for decision making.

Further research should also be conducted to evidence the characteristics of purple maize which 
Table 1 - Metabolites detected in the samples of purple maize collected in Peru from March to April 2017.

\begin{tabular}{|c|c|c|c|}
\hline Metabolites & Frequency $(\%)$ & Mean concentration of positive samples $\left(\mu \mathrm{g} \mathrm{kg}^{-1}\right)$ & Maximum concentration $\left(\mu \mathrm{g} \mathrm{kg}^{-1}\right)$ \\
\hline AME & $9(14.3)$ & 23.3 & 86.78 \\
\hline $\mathrm{AOH}$ & $5(7.9)$ & 1.8 & 3.75 \\
\hline TEN & $0(0.00)$ & $<\mathrm{LQ}$ & --- \\
\hline NEO & $0(0.00)$ & $<\mathrm{LQ}$ & --- \\
\hline NIV & $0(0.00)$ & $<\mathrm{LQ}$ & --- \\
\hline WORT & $0(0.00)$ & $<\mathrm{LQ}$ & --- \\
\hline 3-DON & $0(0.00)$ & $<\mathrm{LQ}$ & --- \\
\hline $15-\mathrm{DON}$ & $0(0.00)$ & $<\mathrm{LQ}$ & --- \\
\hline DON & $0(0.00)$ & $<\mathrm{LQ}$ & --- \\
\hline ZEA & $0(0.00)$ & $<\mathrm{LQ}$ & --- \\
\hline $\mathrm{AFB}_{1}$ & $0(0.00)$ & $<\mathrm{LQ}$ & --- \\
\hline $\mathrm{AFB}_{2}$ & $0(0.00)$ & $<\mathrm{LQ}$ & --- \\
\hline $\mathrm{AFG}_{1}$ & $0(0.00)$ & $<\mathrm{LQ}$ & -- \\
\hline $\mathrm{AFG}_{2}$ & $0(0.00)$ & $<\mathrm{LQ}$ & --- \\
\hline $\mathrm{FB}_{1}$ & $0(0.00)$ & $<\mathrm{LQ}$ & --- \\
\hline $\mathrm{FB}_{2}$ & $0(0.00)$ & $<\mathrm{LQ}$ & --- \\
\hline $\mathrm{FB}_{3}$ & $0(0.00)$ & $<\mathrm{LQ}$ & --- \\
\hline OTA A & $0(0.00)$ & $<\mathrm{LQ}$ & --- \\
\hline OTA $\alpha$ & $0(0.00)$ & $<\mathrm{LQ}$ & --- \\
\hline $\mathrm{T} 2$ & $0(0.00)$ & $<\mathrm{LQ}$ & --- \\
\hline HT2 & $0(0.00)$ & $<\mathrm{LQ}$ & --- \\
\hline DAS & $0(0.00)$ & $<\mathrm{LQ}$ & --- \\
\hline FUSA-x & $0(0.00)$ & $<\mathrm{LQ}$ & --- \\
\hline CPA & $0(0.00)$ & $<\mathrm{LQ}$ & --- \\
\hline GL & $0(0.00)$ & $<\mathrm{LQ}$ & --- \\
\hline AGC & $0(0.00)$ & $<\mathrm{LQ}$ & --- \\
\hline CITREO & $0(0.00)$ & $<\mathrm{LQ}$ & --- \\
\hline
\end{tabular}

$<\mathrm{LQ}=$ Below the limit of quantification. $\mathrm{AME}=$ alternariolmetileter, $\mathrm{AOH}=$ alternariol, $\mathrm{TEN}=$ tentoxin, $\mathrm{NEO}=$ neosolaniol, $\mathrm{NIV}=$ nivalenol, WORT=wortmannin, 3DON=3-acetyl deoxynivalenol, 15DON=15-acetyl deoxynivalenol, DON=deoxynivalenol, ZEA=zearalenone, $\mathrm{AFB}_{1}=$ aflatoxin $\mathrm{B}_{1}, \mathrm{AFB}_{2}=$ aflatoxin $\mathrm{B}_{2}, \mathrm{AFG}_{1}=$ aflatoxin $\mathrm{G}_{1}, \mathrm{AFG}_{2}=$ aflatoxin $\mathrm{G}_{2}, \mathrm{FB}_{1}=$ fumonisin $\mathrm{B}_{1}, \mathrm{FB}_{2}=$ fumonisin $\mathrm{B}_{2}, \mathrm{FB}_{3}=$ fumonisin $\mathrm{B}_{3}$, OTA $\mathrm{A}=$ ochratoxin A, OTA $\alpha=$ ochratoxin $\alpha, \mathrm{T} 2=\mathrm{T}-2$ toxin, HT2=HT-2 toxin, DAS=diacetoxiscirpenol, FUSA-x=fusarenon $\mathrm{x}$, $\mathrm{CPA}=$ cyclopiazonic acid, $\mathrm{GL}=$ gliotoxin, $\mathrm{AGC}=$ agroclavin, $\mathrm{CITREO}=$ citreoviridin.

hold the capacity of inhibiting fungal proliferation and consequently, mycotoxins development. Likewise, the nutritional properties of this culture should be better understood so that it could be used for the production of a greater diversity of items and thus expand its share in the market.

The methodology employed in the present research is effective to determine 27 mycotoxins simultaneously by using LC-MS/MS. No quantifiable levels of mycotoxins with guidance levels within the Brazilian legislation were detected. Of the 27 analyzed mycotoxins, only alternariolmetileter and alternariol were reported. Thus, the Peruvian purple maize may be considered a promising alternative to be used in the manufacturing of a variety of products.

\section{ACKNOWLEDGEMENTS}

The authors acknowledge the research was financed in part by the Coordenação de Aperfeiçoamento de Pessoal de Nível Superior (CAPES), Brasil - Finance code 001.

\section{DECLARATION OF CONFLICT OF INTERESTS}

The authors declare no conflict of interests. The founding sponsors had no role in the design of the study; in the collection, analyses, or interpretation of data; in the writing of the manuscript; and in the decision to publish the results.

\section{AUTHORS' CONTRIBUTIONS}

The authors contributed equally to the manuscript.

Ciência Rural, v.49, n.11, 2019. 


\section{REFERENCES}

ADEYEYE, S.A.O. Aflatoxigenic fungi and mycotoxins in food: a review. Critical Reviews in Food Science and Nutrition, p.1-13. 2019. Available from: <https://www.tandfonline.com/doi/abs/10 1080/10408398.2018.1548429? journalCode=bfsn20>. Accessed: Feb. 5, 2019. doi: 10.1080/10408398.2018.1548429.

ARROYO, J. et al. Reducción del colesterol y aumento de la capacidad antioxidante por el consumo crónico de maíz morado (Zea mays L) en ratas hipercolesterolémicas. Revista Peruana de Medicina Experimental y Salud Publica, v.24, p.157-162, 2007. Available from: <http://www.scielo.org.pe/scielo.php?script=sci arttext\&pid $=$ S1726-46342007000200010\&nrm $=$ iso $>$. Accessed Jan. 03, 2019

BELHASSEN, H. et al. Zearalenone and its metabolites in urine and breast cancer risk: A case-control study in Tunisia. Chemosphere, v.128, p.1-6, 2015. Available from: <https://www.ncbi.nlm.nih. gov/pubmed/25602441>. Accessed: Jan. 03, 2019. doi: 10.1016/j. chemosphere.2014.12.055.

BOUTRIF, E.; CANET, C. Mycotoxin prevention and control FAO programmes. v.6, p.681-694, 1998. Available from: <https://www. revmedvet.com/artdes-us.php?id=143>. Accessed: Jan. 03, 2019.

BRASIL. Agência Nacional de Vigilância SanitáriaANVISA. Resolução da Diretoria Colegiada - RDC n ${ }^{\circ} 7$, de 18 de fevereiro de 2011 que dispõe sobre limites máximos tolerados (LMT) para micotoxinas em alimentos. Diário Oficial da União, Brasília, DF, 2011.

EFSA: Panel on contaminants in the food chain: scientific opinion on the risk for animal and public health related to the presence of Alternaria toxins in feed and food. EFSA J 2011, 9:2407.

HAJNAL, E.J. et al. Possibility of Alternaria toxins reduction by extrusion processing of whole wheat flour. Food Chemistry, v. 213 p.784-790, 2016. Available from: <https://www.ncbi.nlm.nih.gov/ pubmed/27451248>. Accessed: Feb. 01, 2019. doi: 10.1016/j. foodchem.2016.07.019

HUSSEIN, S.H.; BRASSEL, M. Toxicity, metabolism and impact of mycotoxins on human and animals. Toxicology, v.167, p.101134, 2001. Available from: <https://www.ncbi.nlm.nih.gov/ pubmed/11567776>. Accessed: Feb. 04, 2019.

JAMES, A.; ZIKANKUBA, V.L. Mycotoxins contamination in maize alarms food safety in sub-Sahara Africa. Food Control, v.90, p.372-381, 2018. Available from: $<$ https://www.sciencedirect.
com/science/article/pii/S0956713518301257>. Accessed: Feb. 03, 2019. doi: 10.1016/j.foodcont.2018.03.018.

KROUT-GREENBERG, N.D. et al. Preliminary study to assess mycotoxin concentrations in whole corn in the California feed supply. Journal Dairy Science, v.96, p.2705-2712, 2013. Available from: <https://www.sciencedirect.com/science/article/ pii/S0022030213001318>. Accessed: Jan. 29, 2019. doi: 10.3168/ jds.2012-5957.

LEE, H.B. et al. Alternaria in Food: ecophysiology, mycotoxin production and toxicology. Mycobiology, v.43, p.93-106, 2015. Available from: <https:/www.ncbi.nlm.nih.gov/pmc/articles/ PMC4505009/>. Accessed: Feb. 04, 2019. doi: 10.5941/ MYCO.2015.43.2.93

MORENO, E.C. et al. Co-occurrence of mycotoxins in corn samples from the Northern region of Paraná State, Brazil. Food Chemistry, v.116, p.220-226, 2009. Available from: <https:// www.sciencedirect.com/science/article/pii/S0308814609002258>. Accessed: Feb. 05, 2019. doi: 10.1016/j.foodchem.2009.02.037.

MUNKVOLD, G.P. et al. Mycotoxins in Corn: Occurrence, Impacts, and Management. Corn, 235-287, 2019. Available from: <https:// www.sciencedirect.com/science/article/pii/B9780128119716000097>. Accessed: Feb. 01, 2019. doi:10.1016/b978-0-12-811971-6.00009-7.

PATRIARCA, A.; PINTO, V.F. Alternaria. Reference Modulein Food Science. Elsevier, 2018, 1-8. Available from: $<$ https://www. researchgate.net/publication/325936280 Alternaria>. Accessed: Feb. 05, 2019. doi: 10.1016/B978-0-08-100596-5.22572-9>.

SERRANO, A.B. Co-occurrence and risk assessment of mycotoxins in food and diet from Mediterranean area. Food Chemistry, v.135, p.423-429, 2012. Available from: <https://www.sciencedirect. com/science/article/pii/S0308814612005304>. Accessed: Feb. 03, 2019. doi: 10.1016/j.foodchem.2012.03.064.

TIEMANN, U. et al. The mycotoxins alternariol and alternariol methyl ether negatively affect progesterone synthesis in porcine granulosa cells in vitro. Toxicology Letters, v.186, p.139145, 2009. Available from: <https://www.ncbi.nlm.nih.gov/ pubmed/19429235>. Accessed: Feb. 06, 2019. doi: 10.1016/j. toxlet.2009.01.014.

VEJDOVSZKY, K. et al. Synergistic estrogenic effects of fusarium and alternaria mycotoxins in vitro. Arch toxicol, v.9, p.1447-1460, 2017. Available from: <https://www.ncbi.nlm.nih. gov/pubmed/27401186>. Accessed: Jan. 27, 2019. doi: 10.1007/ s00204-016-1795-7. 